\title{
PROSES PENGEMBANGAN ORGANISASI KURIKULUM DI INDONESIA
}

\section{Aset Sugiana*}

\begin{abstract}
Abstrak: Organisasi kurikulum merupakan alat mempermudah untuk mencapai keberhasilan siswa dalam mempelajari bahan pelajaran secara efektif. Kegiatan belajar mengajar yang berlangsung di kelas tanpa kurikulum yang jelas akan menyebabkan siswa kurang mengerti pelajaran yang disampaikan. Mengorganisasi kurikulum berarti memilih tujuan-tujuan yang jelas dan objektif serta sesuai dengan kebutuhan dan minat peserta didik. Ada banyak unsur yang terdapat dalam organisasi kurikulum yang bisa menjadi acuan, yaitu: (1) Konsep, (2) Generalisasi, (3) Keterampilan, dan (4) Nilai-nilai. Ada beberapa kriteria dalam merumuskan organisasi kurikulum yang efektif, yaitu: (1) Ruang lingkup bahan (scope), (2) Urutan (sequance), dan (3) Penempatan bahan (grade placement).
\end{abstract}

Kata Kunci: Pengembangan, Organisasi, Kurikulum

$\mathrm{P}$ endidikan formal di sekolah merupakan tempat siswa mendapatkan ilmu pengetahuan melalui kegiatan belajar mengajar. Kurikulum merupakan alat yang sangat penting bagi keberhasilan peserta didik. Tanpa kurikulum yang sesuai dan tepat akan sulit untuk mencapai tujuan dan sasaran pendidikan yang diinginkan. dengan kurikulum yang sesuai dan tepat, maka dapat diharapkan sasaran dan tujuan pendidikan akan dapat tercapai secara maksimal (Nasution 1994, v). Salah satu aspek yang perlu dipahami dalam pengembangan kurikulum adalah aspek yang berkaitan dengan organisasi kurikulum. Organisasi kurikulum

* Program Pascasarjana Prodi Pendidikan Agama Islam Fakultas Ilmu Tarbiyah dan Keguruan Universitas Islam Negeri Sunan Kalijaga Yogyakarta. Jalan Laksda Adisucipto, Caturtunggal, Kec. Depok, Kabupaten Sleman, Daerah Istimewa Yogyakarta, 085208870710, Asetsugiana@gmail.com 
merupakan suatu dasar yang penting sekali dalam pembinaan kurikulum dan bertalian erat dengan tujuan program pendidikan yang hendak dicapai, karena bentuk kurikulum turut menentukan bahan pelajaran, urutannya dan cara menyajikannya kepada muridmurid (Nasution 1994, 176).

Organisasi kurikulum merupakan pola atau desain bahan kurikulum yang tujuannya untuk mempermudah siswa dalam memperlajari bahan pelajaran dapat dicapai secara efektif. Tujuan pendidikan yang dirumuskan dapat mempengaruhi pola atau desain kurikulum karena tujuan tersebut dapat menentukan pola atau kerangka untuk memilih, merencanakan, dan melaksanakan segala pengalaman dan kegiatan belajar di sekolah (Rusman 2009, 59-60). Organisasi kurikulum tertentu sangat mempengaruhi bentukbentuk pengalaman apakah yang akan disajikan kepada anak-anak, dan tentunya akan mempermudah dalam mencapai tujuan pendidikan.

\section{Pengembangan Organisasi Kurikulum}

\section{Pengertian dan Konsep Organisasi Kurikulum}

Mengutip pendapat Audrey dan Howard Nichools, Oemar Hamalik mengemukakan bahwa pengembangan kurikulum (curriculum development) adalah "the planning of learning opportunities intended to bring about certain desired in pupils, and assessment of the extend to whice these changes have taken place". Artinya, pengembangan kurikulum adalah perencanaan kesempatan-kesempatan belajar yang dimaksudkan untuk membawa peserta didik ke arah perubahan-perubahan yang diinginkan serta menilai hingga sejauh mana perubahan-perubahan telah terjadi pada diri peserta didik (Hamalik 2007, 96).

Organisasi kurikulum, yaitu pola atau bentuk bahan pelajaran disusun dan disampaikan kepada murid-murid (Nasution 1994, 176). Muhammad Ali menyatakan bahwa organisasi kurikulum merupakan suatu cara menyusun bahan-bahan atau pengalaman belajar yang ingin dicapai (Ali 2005, 108). Organisasi kurikulum 
adalah susunan komponen kurikulum, seperti konten kurikulum, kegiatan dan pengalaman belajar, yang diorganisasi menjadi mata pelajaran, program, lessons, topik, unit, dan sebagainya untuk mencapai efektivitas pendidikan (Ansyar 2015, 371). Organisasi kurikulum adalah susunan pengalaman dan pengetahuan baku yang harus disampaikan dan dilakukan peserta didik untuk menguasai kompetensi yang telah ditetapkan (Arifin 2011, 94). Pengalaman tersebut ada yang langsung dan ada yang tidak langsung, yaitu: a. Pengalaman langsung adalah pengalaman yang diperoleh peserta didik sebagai hasil interaksi secara langsung dengan dunia sekitarnya. Misalnya, pengaruh kegiatan eksperimen di ruang laboratorium, pengaruh keaktifan peserta didik dalam kegiatan pembelajaran, dan sebagainya. b. Pengalaman tidak langsung adalah pengalaman yang diperoleh peserta didik melalui perantara, seperti pengalaman yang diperoleh dari buku sumber, dan menonton televisi. Pengalaman tidak langsung tersebut dapat berbentuk pengetahuan baku yang memiliki sifat dinamis. Pengetahuan baku tersebut memungkinkan untuk berkembang sehingga memerlukan peninjauan peningkatan dan pemutakhiran sesuai dengan perkembangan zaman (Arifin 2011, 94). Oleh karena itu, dipandang perlu ada reorganisai kurikulum.

Organisasi kurikulum sangat terkait dengan pengaturan bahan pelajaran yang ada dalam kurikulum, sedangkan yang menjadi sumber bahan pelajaran dalam kurikulum adalah nilai budaya, nilai sosial, aspek siswa dan masyarakat, serta ilmu pengetahuan dan teknologi (Rusman 2009, 60). Organisasi kurikulum berhubungan erat dengan kualitas kegiatan dan pengalaman belajar peserta didik. Organisasi kurikulum harus dipilih dan diatur sedemikian rupa untuk dikembangkan lebih luas dan lebih mendalam sehingga peserta didik memperoleh sesuatu yang berharga dari program pendidikan yang telah ditetapkan. Menurut Jhon D. McNeil tidak ada teori organisasi kurikulum yang dapat dianggap memadai. Sekalipun demikian, terdapat beberapa konsep dan prinsip yang dapat diterapkan dalam teori dan praktik. Para pengembang kurikulum diharapkan dapat mengembangkan berbagai program 
pendidikan yang lebihbersifat komprehensif, konsisten, dan efektif. Kegiatan belajar di sekolah tentu berbeda dengan kegiatan belajar di luar sekolah. Di sekolah, semua kegiatan dan pengalamn belajar diatur dan diorganisasikan secara formal, terutama berkaitan dengan kapan dan di mana kegiatan belajar dilakukan. Sekalipun demikian, apa yang harus dipelajari peserta didik tetap harus terstruktur, terutama berkaitan dengan mata pelajaran (Arifin 2011, 94-95).

Adapun unsur-unsur yang terdapat dalam organisasi kurikulum, antara lain: a). Konsep, yaitu definisi secara singkat dari sekelompok fakta atau gejala. Konsep merupakan definisi dari apa yang perlu diamati, konsep menentukan adanya hubungan empiris. Hampir setiap bentuk organisasi kurikulum dibangun berdasarkan konsep, seperti peserta didik, masyarakat, kebudayaan, kuantitas, dan kualitas, ruangan, dan evolusi. b). Generalisasi, yaitu kesimpulan-kesimpulan yang merupakan kristalisasi dari suatu analisis. Kita harus membedakan antara kesimpulan dan rangkuman. Banyak orang yang keliru dalam menarik kesimpulan karena apa yang dilakukannya adalah membuat rangkuman. Misalnya, setiap orang baik sebagai subjek maupun sebagai objek berprilaku secara manusiawi. c). Keterampilan, yaitu kemampuan dalam merencanakan organisasi kurikulum dan digunakan sebagai dasar untuk menyusun program yang berkesinambungan. Misalnya, organisasi pengalaman belajar berhubungan dengan keterampilan komprehensif, keterampilan dasar untuk mengerjakan matematika, dan keterampilan menginterpretasikan data. d). Nilai-nilai, yaitu norma atau kepercayaan yang diagungkan, sesuatu yang bersifat absolut untuk mengendalikan perilaku. Mislanya, menghargai diri sendiri, menghargai kemuliaan dan kedudukan setiap orang tanpa memperhatikan ras, agama, kebangsaan, dan status sosial-ekonomi (Arifin 2011, 96-97).

Mengorganisasi unsur-unsur berarti memilih tujuan-tujuan yang jelas dan objektif serta sesuai dengan kebutuhan dan minat peserta didik. Jika tujuan kurikulum berkaitan dengan masalah teknis dan kejuruan, maka keterampilan adalah unsur yang tepat untuk 
dipergunakan. Jika tujuan kurikulum berkaitan dengan domain moral dan etika sebagai fungsi dan integratif, maka nilai-nilai merupakan unsur organisasi yang tepat.

\section{Model Organisasi Kurikulum}

Berikut ini akan dijelaskan beberapa model organisasi kurikulum, yaitu (Arifin 2011, 97-103): a. Subject Matter Curriculum (Pendekatan Mata Pelajaran). Subject matter curriculum adalah organisasi kurikulum yang tertua dan banyak digunakan di banyak negara. Subject matter curriculum adalah organisasi isi pendidikan dalam bentuk mata pelajaran yang disajikan dan diberikan kepada para siswa secara terpisah-pisah (Ahmad, dkk 1998, 125). Misalnya, mata pelajaran berhitung, aljabar, ilmu ukur, sejarah, ekonomi, geografi, dan ilmu bumi. Mata pelajaran-mata pelajaran tersebut terpisah-pisah (isolated) satu sama lain, sehinggu tampak mudah diatur dalam pelaksanaannya. Sekalipun guru mengajar untuk satu kelas (seperti guru kelas di Sekolah Dasar, tetapi tetap dalam mengajarkan mata pelajarannya secara terpisah-pisah dan tidak ada korelasi satu dengan lainnya. sifat yang terpisah-pisah itu memudahkan pula bagi guru untuk membelajarkan peserta didik, termasuk melakukan penilaian proses dan hasil belajar peserta didik. Peserta didik lebih banyak melakukan kegiatan belajar menghafal pelajaran atau membuat rangkuman daripada melakukan diskusi atau pemecahan masalah, karena utama kurikulum adalah agar peserta didik menguasai pengetahuan (Arifin 2011, 97-98).

Berdasarkan uraian di atas, maka dapat diidentifikasi ciri-ciri organisasi subject matter curriculum sebagai berikut (Arifin 2011, 98): 1) Kurikulum terdiri atas sejumlah mata pelajaran yang terpisahpisah, tidak ada hubungan dan kaitannya satu sama lain, 2) Mata pelajaran-mata pelajaran tersebut berdiri sendiri sebagai suatu disiplin ilmu, 3) Tujuan kurikulum adalah untuk menguasai pengetahuan, 4) Mata pelajaran tidak disusun sesuai dengan kebutuhan peserta didik dan masyarakat, 5) Strategi banyak menggunakan teknik penuangan, 6) Guru berperan dan bertanggung jawab sebagai guru sebagai guru mata pelajaran, 7) 
Proses pembelajaran lebih berpusat kepada guru, sementara peserta didik bersifat pasif, dan 8) Teknik penilaian lebih banyak menggunakan tes dengan fokus domain kognitif. b. Correlated Curriculum (Mata Pelajaran Gabaungan). Pada dasarnya organisasi kurikulum ini menghendaki agar mata pelajaran itu satu sama lain ada hubungannya, bersangkut paut (correlated) walaupun mungkin batas-batas yang satu dengan yang lain masih dipertahankan (Suryosubroto 2005, 3). Mengingat sucject centered curriculum banyak memiliki kelemahan, maka diadakanlah upaya-upaya untuk memperbaiki, memodifikasi, dan menyempurnakannya, antara lain mengorelasikan antara mata pelajaran yang satu dengan mata pelajaran yang lain. bentuk korelasi semacam ini disebut correlated curriculum. Misalnya, ketika mengajarkan mata pelajaran ilmu bumi tentang tanah, maka dikorelasikan dengan mata pelajaran sejarah atau berhitung. Di dalam korelasi formal, beberapa guru mata pelajaran sengaja mengadakan pertemuan formal untuk merencanakan secara bersama-sama tentang apa dan bagaimana mengorelasikan materi pelajaran, sedangkan dalam korelasi informal, seorang guru mata pelajaran A (misalnya) meminta secara informal kepada guru mata pelajaran B untuk mengorelasikan materi pelajarannya dengan pelajaran yang akan disampaikan guru pelajaran A (Arifin 2011, 99).

Ciri-ciri kurikulum korelasi ini, antara lain (Arifin 2011, 99): 1) Adanya korelasi antarmata pelajaran, 2) Adanya upaya untuk menyesuaikan mata pelajaran dengan masalah kehidupan seharihari, termasuk kebutuhan dan minat peserta didik, 3) Tujuan kurikulum adalah menguasai pengetahuan, 4) Pelayanan perbedaan individual masih sangat terbatas, 5) Dalam proses pembelajaran, guru banyak berperan aktif, 6) Peran peserta didik mulai diaktifkan, dan 7) Penilaian lebih difokuskan kepada domain cognitive, kendati pun domain lain sudah mulai dikembangkan. Melalui kurikulum korelasi, tampak ada penggabungan ke arah kesatuan mata pelajaran, sekalipun antara mata pelajaran yang satu dengan lainnya masih terpisah. c. Broad Field Curriculum (Cakupan luas). Ada juga korelasi antara beberapa mata pelajaran (interdisipliner) yang lebih 
jauh sehingga tidak tampak lagi batas-batas mata pelajaran dalam satu rumpun. Korelasi semacam ini merupakan fusi antara beberapa mata pelajaran serumpun dan memiliki ciri-ciri yang sama. Organisasi ini disebut dengan bidang studi (broad field). Misalnya, antara mata pelajaran sejarah, geografi, ekonomi, difusikan menjadi bidang studi Ilmu Pengetahuan Sosial (IPS), mata pelajaran kimia, fisika, biologi difusikan menjadi bidang studi Ilmu Pengetahuan Alam (IPA), dan mata pelajaran aljabar, ilmu ukur, ndan geometri difusikan menjadi bidang studi matematika. Tujuan kurikulum bidang studi adalah untuk mengintegrasikan pengetahuan anak dan mencegah penguasaan bahan yang banyak, dangkal, dan terlepaslepas sehingga mudah dilupakan dan tidak fungsional. Bentuk organisasi kurikulum ini mulai digunakan di Indonesia sejak tahun 1975. Hilda Taba menegaskan agar tercapai gabungan yang nyata, maka perlu adanya integrating threads dan focusing centers berupa tujuan, prinsip-prinsip umum, teori atau masalah masyarakat dan kehidupan yang dapat mewujudkan gabungan itu secara wajar (Arifin 2011, 99-100). d. Integrated Curriculum (Kurikulum Terpadu). Kurikulum terpadu adalah kurikulum yang menyajikan bahan pembelajaran secara unit dan keseluruhan tanpa mengadakan batasbatas satu pelajaran denagn yang lainnya (Sukiman 2013, 88-89). Jenis organisasi ini disusun berdasarkan analisis bidang kehidupan atau kegiatan utama manusia dalam masyarakat yang disebut social functions atau major areas of living, yang meliputi perlindungan dan pelastarian hidup, kekayaan dan sumber alam, produksi barang dan jasa distribusinya, konsumsi benda dan jasa komunikasi dan transportasi benda dan manusia, reakreasi, ekspresi rasa keindahan, ekspresi rasa keagamaan, pendidikan, perluasan kebebasan, integrasi kepribadian dan penelitian (Arifin 2011, 100-101). e. Core Curriculum. Istilah core curriculum merujuk pada suatu rencana yang mengorganisasikan dan mengatur (scheduling) bagian terpenting dari program pendidikan umum di sekolah. Founce dan Bossing mengistilahkan core curriculum dengan merujuk pada pengalaman belajar yang fundamental bagi peserta didik, karena pengalaman belajar berasal dari: 1) kebutuhan atau dorongan secara individual 
maupun umum, dan 2) kebutuhan secara sosial dan sebagai warga negara masyarakat demokritas (Idi 2007, 150). Organisasi kurikulum ini bertitik tolak dari mata pelajaran tertentu sebagai core. Menurut Caswell sebagai pelopor organisasi kurikulum ini, "core is a continuous, careful planned series of experiences which are based on common concern to all youth". The core curriculum as the part of the total curriculum which is for all pupils, which seeks general education objectives, which is organized withhout strict regard for subject lines, and which is scheduld for proportionately longer blocks of time. Berdasarkan pengertian, maka pada dasarnya kurikulum ini (core curriculum) merupakan bagian dari kurikulum secara keseluruhan dan termasuk kurikulum terpadu. Alasannya adalah kurikulum inti menggunakan bahan dari segala disiplin ilmu atau mata pelajaran yang diperlukan untuk memecahkan masalah yang dihadapi peserta didik, termasuk juga bahan dari lingkungan (Idi 2007, 102). f. Activity Curriculum. Activity curriculum sering juga disebut experience curriculum. Organsasi kurikulum ini tidak memiliki struktur yang normal dan tidak dirancang sebelumnya. Isi kurikulum ini ditentukan berdasarkan kebutuhan dan minat peserta didik serta membantu peserta didik dalam memilih kebutuhan dan minat yang dianggap penting. Kurikulum harus disusun bersama oleh guru dan peserta didik dengan penekanan utama pada prosedur pemecahan masalah. Kelebihan kurikulum ini antara lain sesuai dengan kebutuhan dan minat peserta didik, memperhatikan perbedaan individual, dan memberikan bekal kemampuan khusus untuk hidup di masyarakat. Sedangkan kekurangannya, antara lain kebutuhan dan minat peserta didik benlum tentu relevan dengan realitas kehidupan yang begitu kompleks, kontinuitas dan urutan bahan masih sangat lemah, dan memerlukan guru yang kompeten dan profesional yang tidak hanya menguasai mata pelajaran atau bidang studi, tetapi juga memiliki kemampuan sosial (Idi 2007, 103).

\section{Faktor-faktor dalam Organisasi Kurikulum}

Menurut Hilda Taba, organisasi kurikulum dapat dipandang sebagai one of the most potent factors in determining how learning proceeds. 
Oleh sebab itu, ada beberapa faktor yang harus dipertimbangkan dalam organisasi kurikulum, yaitu: a. Ruang lingkup (scope). Ruang lingkup kurikulum menunjukkan keseluruhan, keluasan atau kedalaman, dan batas-batas bahan pelajaran yang akan disampaikan kepada peserta didik. Bahan pelajaran tersebut merupakan bahan yang terseleksi karena dianggap penting dan sesuai dengan tugastugas perkembangan peserta didik. Dikatakan penting karena peserta didik mempunyai kepentingan, antara lain ingin melanjutkan ke jenjang pendidikan yang lebih tinggi, ingin masuk ke dalam dunia kerja, dapat beradaptasi diri dengan lingkungan, dapat bersosialisasi dan memecahkan masalah-masalah sosial, menghargai karya dan seni, serta ingin memiliki nilai-nilai agama yang baik. Ruang lingkup kurikulum tidak dapat dipisahkan dari kebutuhan peserta didik, kebutuhan keluarga, masyarakat, bangsa, dan negara. Ruang lingkup bahan pelajaran juga harus dengan visi, misi, dan tujuan pendidikan nasional, standar kompetensi lulusan, dan standar kompetensi mata pelajaran yang telah ditetapkan (Idi 2007, 104). Sebagai telah dijelaskan dalam jenis-jenis organisasi kurikulum bahwa setiap organisasi mempunyai ruang lingkup bahan pelajaran yang berbeda sehingga kegiatan dan pengalaman belajar pun juga berbeda. Setelah memilih dan menentukan ruang lingkup bahan pelajaran, kemudian disusun dalam organisasi kurikulum tertentu sesuai dengan yang diinginkan. b. Urutan (sequence). Urutan bahan pelajaran menunjukkan keteraturan bahan yang akan disampaikan kepada peserta didik, kapan bahan tersebut sebaiknya disampaikan terlebih dahulu dan mana bahan yang akan dipelajari kemudian. Hal ini sangat erat hubungannya dengan tingkat kematangan peserta didik, latar belakang pengalaman atau pengetahuan, kegunaan bahan, dan tingkat kesulitan bahan. Urutan tersebut dapat dilakukan dengan cara, antara lain mulai dari yang kecil hingga yang terbesar, mulai dari yang sederhana sampai yang kompleks, mulai dari keseluruhan sampai dengan bagian-bagian, mulai dari yang mudah sampai dengan yang sulit, mulai dari tingkat pengetahuan sampai dengan tingkat evaluasi, mulai dari dahulu sampai dengan sekarang, dan seterusnya (Idi 2007, 105-106). c. 
Kesinambungan (Continuity). Sering kali kita mendengar kritikan dari pihak perguruan tinggi bahwa kurikulum di tingkat Sekolah Lanjutan Tingkat Atas (SMA/ SMK/ MA) tidak relevan atau masih dangkal karena mahasiswa sulit memahami mata kuliah. Begitu juga kritikan dari pihak SLTA terhadap SLTP (SMP/MTs) dan dari SLTP ke SD/MI. Sebenarnya inti persoalan adalah adanya kesenjangan (gap) antara apa yang ada (das sein) dengan apa yang seharusnya (das sollen), tumpang tindih (overlapping) antara mata pelajaran yang satu dengan mata pelajaran yang lain bahkan antara topik yang satu dengan topik yang lain, dan ketidaksinambungan bahan pelajaran dan pengalaman belajar. Contohnya, peserta didik sudah belajar bahasa Inggris dari SMP sampai perguruan tinggi (lebih kurang 10 tahun), ternyata belum dapat berkomunikasi dengan bahasa Inggris dengan baik (Idi 2007, 106). d. Terpadu (Integrated). Faktor ini berangkat dari asumsi bahwa bidang-bidang kehidupan memerlukan pemecahan secara multidisiplin. Artinya, jika guru menggunkan subject centered curriculum, maka besar kemungkinan pengetahuan yang diperoleh peserta didik menjadi terlepas-lepas dan tidak fungsional. Untuk itu, perlu adanya fokus bahan pelajaran yang terpadu, baik konsep, prinsip maupun masalah-masalah yang perlu dipecahkan sehingga memungkinkan penggunaan multidisiplin secara pungsional. Keterpaduan ini dapat dilakukan dalam bentuk kurikulum korelasi, kurikulum bidang studi, atau kurikulum terpadu berdasarkan bidang-bidang kehidupan. Untuk mencapai pemahaman yang utuh dan menyeluruh, maka keterpaduan ini bukan hanya dilakukan oleh guru dalam berbagai mata pelajaran, tetapi juga oleh peserta didik melalui pengetahuan dari berbagai sumber belajar yang saling berhubungan (Idi 2007, 107). e. Keseimbangan (Balance). Faktor keseimbangan yang dimaksudkan di sini adalah keseimbangan isi dan bahan pelajaran yang akan disampaikan kepada peserta didik dan keseimbangan proses pembelajaran. Keseimbangan isi berkaitan dengan seberapa besar pentingnya suatu bahan pelajaran bagi kehidupan peserta didik. Kalau hanya berbicara tentang kepentingan tentu semua bahan pelajaran adalah penting, tetapi 
kepentingan tersebut harus dikaitkan dengan pembentukan pribadi peserta didik secara utuh dan menyeluruh. f. Waktu (Times). Alokasi waktu harus dipertimbangkan dalam organisasi kurikulum, dalam arti apakah suatu mata pelajaran, mislanya, akan diberikan selama 2 jam perlajaran per hari, satu minggu, satu bulan, satu semester, satu tahun atau tiap tahun. Sering terjadi perbedaan pendapat tentang alokasi waktu, antara pengembang kurikulum di tingkat pusat dengan guru mata pelajaran di sekolah. Hal ini biasanya pegangan bersama, distribusi waktu ditentukan berdasarkan kriteria, antara lain tradisi pengalaman, pertimbangan para pengembang kurikulum, nilai dan manfaat, tingkat kesulitan setiap mata pelajaran, dan standar kompetensi mata pelajaran.

Ada beberapa kriteria dalam merumuskan organisasi kurikulum yang efektif. Menurut Oemar Hamalik, yang perlu diperhatikan dalam penyusunan organisasi kurikulum, yaitu (Hamalik 1980, 103): a. Ruang lingkup bahan (scope) adalah keseluruhan materi pelajaran dan pengalaman yang akan diberikan dari suatu bidang studi atau dari sesuatu pokok bahasan tertentu. Selain itu sesuatu pokok bahasan dan atau sub pokok bahasan juga mengandung ruang lingkupnya tersendiri. Ruang lingkup bahan itu merupakan perincian dari pada pokok atau topic tersebut. Kejelasan tentang perincian bahan tersebut dapat kita peroleh dari dalam buku paket atau sumber pokok dari pelajaran yang telah ditentukan. b. Urutan (sequance) adalah penyusunan bahan pelajaran menurut aturan tertentu secara berurutan, urutan bahannya disusun sedemikian rupa agar menunjukkan sistematika dan memudahkan penyampaian maupun penangkapan oleh para siswa. c. Penempatan bahan (grade placement) adalah penempatan beberapa bahan pelajaran untuk kelas tertentu. Penempatan bahan pelajaran tersebut dihubungkan dengan ruang lingkup bahan dan diserasikan dengan urutan bahan pelajaran.

\section{Catatan Akhir}

Organisasi kurikulum adalah salah satu cara untuk menyusun bahan atau pengalaman belajar yang ingin dicapai. Untuk itu perlu 
dipilih organisasi kurikulum yang efektif dengan kriteria berkesinambungan, berurutan dan terpadu. Organisasi kurikulum, yaitu pola atau bentuk bahan pelajaran disusun dan disampaikan kepada murid-murid. Adapun unsur-unsur yang terdapat dalam organisasi kurikulum, antara lain: a. konsep, b. generalisasi, c. keterampilan, d. nilai-nilai.(Hamalik 1980, 96-97)

Ada enam model organisasi kurikulum, yaitu: a. Subject Matter Curriculum (Pendekatan Mata Pelajaran), b. Correlated Curriculum (Mata Pelajaran Gabaungan), c. Broad Field Curriculum (Cakupan luas), d. Integrated Curriculum (Kurikulum Terpadu), e.Core Curriculum, f. Activity Curriculum. Adapun faktor yang harus dipertimbangkan dalam organisasi kurikulum, yaitu: a. Ruang lingkup (scope), b. Urutan (sequence), c. Kesinambungan (Continuity), d. Terpadu (Integrated), e. Keseimbangan (Balance), e. Waktu (Times).

\section{Implikasi}

Penelitian ini telah menunjukkan bahwa pengorganisasian kurikulum penting disusun dengan semaksimal mungkin dalam rangka mencapai tujuan pendidikan yang diinginkan. Dalam organisasi kurikulum terdapat hal-hal yang harus diperhatikan mengingat kebutuhan peserta didik dan minat dan bakat peserta didik yang berbeda. Hasil penelitian ini memberikan beberapa implikasi, antara lain: (1) implikasi terhadap pengembangan organisasi kurikulum, (2) implikasi terhadap penyusun kurikulum kebutuhan terhadap peserta didik, dan (3) implikasi terhadap pendidikan tenaga kependidikan.

\section{Daftar Pustaka}

Ahmad, dkk. 1998. Pengembangan Kurikulum. Bandung: Pustaka Setia.

Ali, Muhammad. 2005. Pengembangan Kurikulum di Sekolah. Bandung: Sinar Baru Algesindo.

Ansyar, Mohamad. 2015. Kurikulum, Fondasi, Desain, dan Pengembangan. Jakarta: Prenada Media Group. 
Arifin, Zainal. 2011. Konsep dan Model Pengembangan Kurikulum. Bandung: Remaja Rosda Karya.

Hamalik, Oemar. 1980. Pengembangan Kurikulum (Dasar-Dasar Perkembangannya). Bandung: Mandar Maju.

2007. Manajemen Pengembangan Kurikulum. Bandung: Remaja Rosda Karya.

Idi, Abdullah. 2007. Pengembangan Kurikulum Teori dan Praktik. Yogyakarta: Ar-Ruzz Media.

Nasution. 1994. Asas-asas Kurikulum. Jakarta: Bumi Aksara.

Rusman. 2009. Manajemen Kurikulum. Jakarta: Raja Grafindo Persada.

Sukiman. 2013. Pengembangan Kurikulum (Teori dan Praktik pada Perguruan Tinggi). Yogyakarta: UIN Sunan Kalijaga.

Suryosubroto. 2005. Tatalaksana Kurikulum. Jakarta: Rineka Cipta. 